Available online at GSC Online Press Directory

GSC Biological and Pharmaceutical Sciences

e-ISSN: 2581-3250, CODEN (USA): GBPSC2

Journal homepage: https://www.gsconlinepress.com/journals/gscbps

(RESEARCH ARTICLE)

\title{
Analgesic activity of the combined extract of sukun (Artocarpus altilis) and melinjo (Gnetum gnemon L.) Leaves in mice
}

\author{
Mashuri Yusuf 1, Lilik Koernia Wahidah 1, Subur Widodo 1, Puspita Gita Sari ${ }^{1}$, Mohammad Kanedi 2,* \\ ${ }^{1}$ Department of Pharmacy Faculty of Math and Sciences, Tulangbawang University, Bandar Lampung, Indonesia. \\ ${ }^{2}$ Department of Biology Faculty of Math and Sciences, University of Lampung, Bandar Lampung, Indonesia.
}

Publication history: Received on 15 October 2020; revised on 21 October 2020; accepted on 25 October 2020

Article DOI: https://doi.org/10.30574/gscbps.202013.1.344

\begin{abstract}
Analgesic is any drug used to achieve analgesia-relieve from pain, without blocking the conduction of nerve impulses. Sukun (Artocarpusaltilis) and melinjo (Gnetumgnemon L.) are plants that can be expected to have analgesic properties because they contain bioactive that can inhibit biosynthesis of prostaglandins, a hormone-like pain reducing agent. To determine analgesic effect of two plants in question, the combination extract of melinjo and sukun leaves were treated to mice by applying writhing test. Male mice $(n=28)$ were grouped into seven consisted of two control groups (negative dan positive) and five test groups. The negative control group (KN) received CMC $0.5 \%$, the positive control mice received $1.3 \mathrm{mg} / \mathrm{kg} \mathrm{BW}$ mefenamic acid. Test groups were given leaf extracts of sukun and melinjo with the dose ratios (sukun : melinjo) as follows (200: 0), (150:50), (100:100), (50:150), and (0:200) mg/kg BW respectively. After 15 minutes all mice were pain-induced with $1 \%$ acetic acid intraperitoneally. Stretching activity of the animals was observed every 5 minutes for 1 hour. The result showed that the extracts with a dose ratio of $(150+50) \mathrm{mg} / \mathrm{kg} \mathrm{BW}$ has a comparable anlgesic effects to the mefenamic acid is the most effective combination among other comination doses.
\end{abstract}

Keywords: Analgesic drug; Melinjo; Gnetum gnemon; Sukun; Artocarpus altilis

\section{Introduction}

Health is very important for humans to achieve prosperity and happiness. One of the health problems that occur in humans is pain. Pain is a sensory and emotional feeling that is uncomfortable for the sufferer and pain occurs as a sign of tissue damage. Pain is a symptom of disease caused by chemical or physical mechanical stimulation that exceeds the pain threshold and causes tissue damage with the release of pain mediators such as histamine, bradykin, leukotrienes and prostaglandins [1].

There are various kinds of analgesic drugs commonly used by the public, both in the form of traditional and synthetic medicines. Some examples of analgesic drugs are paracetamol, aspirin, ibuprofen, and mefenamic acid. Long-term use of synthetic drugs can relieve pain, but not a few side effects. The most common side effects are gastrointestinal disorders, blood damage, liver and kidney damage and also allergic skin reactions [2, 3].

One of the plants used as traditional medicine is the melinjo plant (Gnetumgnemon L.). Melinjo plant has benefits in the field of traditional medicine such as shedding urine, curing eye diseases and anemia. This plant has many benefits because almost all of its parts, from flowers, fruit, stems and especially leaves. Melinjo leaves are known to contain saponins, tannins and flavonoids. Related research that has been done previously is the analgetic activity of the ethanol

*Corresponding author: Mohammad Kanedi

Department of Biology Faculty of Math and Sciences, University of Lampung, Bandar Lampung, Indonesia.

Copyright $(2020$ Author(s) retain the copyright of this article. This article is published under the terms of the Creative Commons Attribution Liscense 4.0. 
extract of melinjo leaves (Gnetum gnemon L.) in male white mice which has analgetic power with a concentration of $51.84 \mathrm{mg} / \mathrm{kg} \mathrm{BW}[4]$.

Another plant that has been empirically proven to be used as a pain reliever in toothache, canker sores, itching, joint pain, kidney disease, heart disease and diabetes is the sukun plant (Artocarpus altilis). Sukun leaves contain chemical substances, namely saponins, tannins, flavonoids. Previous research related to the analgesic activity of the ethanol extract of sukun leaves (Artocarpus altilis) against male white mice induced by acetic acid had analgetic power with concentrations of $100 \mathrm{mg} / \mathrm{kg} \mathrm{BW}$ and $200 \mathrm{mg} / \mathrm{kg} \mathrm{BW}[5,6]$.

The problem with painkillers, especially those made from synthetic ingredients such as opioids, is the presence of various side effects such as: kidney disorders, drug dependence, or impaired infant development [7].These facts encourage researchers stay to seek and develop any pain medication from natural sources that are safe with minimal side effects.

In an effort to find a safe analgesic drug, this research was conducted. The melinjo and sukun leaves are known to contain flavonoid compounds that are revealed to inhibit cyclooxygenase enzyme activity. Activity inhibition of the cyclooxygenase enzymes theoretically will decrease the production of prostaglandins and reduces pain [8]. But, given the previous data revealed that the leaf extracts of sukun and melinjo showed different analgesic activity, so in this study we combined the extracts of the two plants.

\section{Material and methods}

\subsection{Plant materials and extraction}

The plant leaf samples of the sukun (Artocarpus altilis) and melinjo (Gnetum gnemonL.) were collected from the village of Kalidadi Kalirejo District, Central Lampung Regency, Lampung Province, Indonesia. Taxonomic determination of the plant was carried out by plant taxonomist at the Botanical Laboratory, Department of Biology, Faculty of Mathematics and Natural Sciences, University of Lampung, Indonesia.

The fresh leaves of the plants were washed and rinsed using running tap water to remove all dirt and impurities. Next, the leaves were chopped into small pieces and then sun-dried under a black cloth cover. The use of a black cloth is intended to prevent the sample from being exposed to UV rays.The dried chopped leaves (400 g) are macerated using $70 \%$ ethanol in a dark glass container. The filtrate were collected by filtration after 24 hours. The solid residues were then re-macerated using the same solvent every 24 hours until the extract is completely clear. Furthermore, the obtained filtrate is evaporated using a rotary evaporator until a viscous extract of melinjo and sukun leaves are obtained.

\subsection{Preparation of the test ingredient}

In this study, all materials given to mice mefenamic acid and ethanol extract of melinjo and sukun leaves were suspended in $0.5 \% \mathrm{CMC}(\mathrm{w} / \mathrm{v})$.A total of $0.5 \mathrm{~g} \mathrm{CMC} \mathrm{was} \mathrm{sprinkled} \mathrm{into} \mathrm{the} \mathrm{mortar} \mathrm{containing} 10 \mathrm{ml}$ of distilled water that had been heated and crushed until homogeneous. The homogenous suspension transfered into measuring flask and then distilled water is added up to $100 \mathrm{~mL}$ of volume. Mefenamic acid tablets (500 mg), the standard drug, were finely ground and in a mortar containing of $10 \mathrm{ml}$ of $5 \% \mathrm{CMC}$.

There were seven different test ingredients prepared in this experiment, namely: vehicles as the negative control (KN); standard drugas positive control (KP); and five different extract dosecombinations of sukun and melinjo leaves namely $\mathrm{K} 1, \mathrm{~K} 2, \mathrm{~K} 3, \mathrm{~K} 4$, and $\mathrm{K} 5$

$\mathrm{KN}$ : Containing only vehicle, $0.5 \% \mathrm{CMC}(\mathrm{w} / \mathrm{v})$;

KP: Contains mefenamic acid at the doses of $1.3 \mathrm{mg} / \mathrm{Kg} \mathrm{BW}$;

$\mathrm{K} 1$ : The test ingredients containing only sukunleavesextract of $200 \mathrm{mg} / \mathrm{kg} \mathrm{BW}$;

K2: Containing sukun leaves extract of $50 \mathrm{mg} / \mathrm{kg}$ and melinjo leaves extract $150 \mathrm{mg} / \mathrm{kg} \mathrm{BW}$;

K3: Containing sukun leaves extract of $100 \mathrm{mg} / \mathrm{kg}$ and melinjo leaves extract $100 \mathrm{mg} / \mathrm{kg} \mathrm{BW;}$

K4: Containing sukun leaves extract of $150 \mathrm{mg} / \mathrm{kg}$ and melinjo leaves extract $50 \mathrm{mg} / \mathrm{kg} \mathrm{BW}$;

K5: The test ingredients containing only melinjo leaves extract of $200 \mathrm{mg} / \mathrm{kg} \mathrm{BW}$.

\subsection{Animals and experimental design}

Male mice $(n=28)$ with a weigh range of $20-30$ g, obtained from Veterinary Centre Lampung, by applying completely randomized design were divided into seven experimental groups (4 mice each). The mice grouping were based on the 
ingredients provided namely KN (negative control), KP (positive control), K1, K2, K3, K4, and K5. All mice were kept for one week to adjust laboratory environment, given pellets and water ad libitum. Before treatments all mice were fasted for 18 hours, but they still have access to drinking water.

\subsection{The test protocol}

Fifteen minutes after the mice received test ingredients, each group of the animals were given $1 \%$ acetic acid (v/v) to induce pain. Wriggling response of the mice was then observed every five minutes for 1 hour. The wriggling responses recorded in this experiment was SAP (Stretch attend posture), a body posture in which the mouse stretches forward and then retracts to its original position, pulls forward and backward their feet while the abdomen presses the floor without moving $[9,10]$. Basing on the analgetic effect test data obtained, the percentage of protection and effectiveness of the test ingredients were determined using the following formula $[11,12]$.

$$
\% \text { Protection }=\frac{A-B}{A} \times 100 \%
$$

Where:

$A=$ Mean number of stretches in negative controls

$\mathrm{B}=$ Average amount of stretches in positive control (test material)

$$
\% \text { Efectiveness }=\frac{\% \text { Protection of a group }}{\% \text { Protection of positive control }} \times 100 \%
$$

\subsection{Phytochemical screening}

To ensure that the breadfruit and melinjo extracts do contain bioactive compounds that have analgesic properties such as alkaloid, flavonoids, saponins, and tannins we conducted qualitative phytochemical screening tests. The presence of the alkaloids was determined using Wagner, Hager and Mayer's test. Tannin, saponin, steroid, and flavonoids were tested using Lead acetate and FeCl3 test, Foam and Haemolysis tests, Salkowski test, Lead acetate test [13].

\subsection{Data Analysis}

The data obtained were analyzed using one way ANOVA with a confidence level of 95\%. The Duncan test was applied in post hoc analysis.

\section{Results and discussion}

The analgesic effect of administering ingredients to the groups of test mice (KN, KP, K1, K2, K3, K4, K5) based on the wriggling response indicated by stretches activity of the animals is presented in Figure 1.

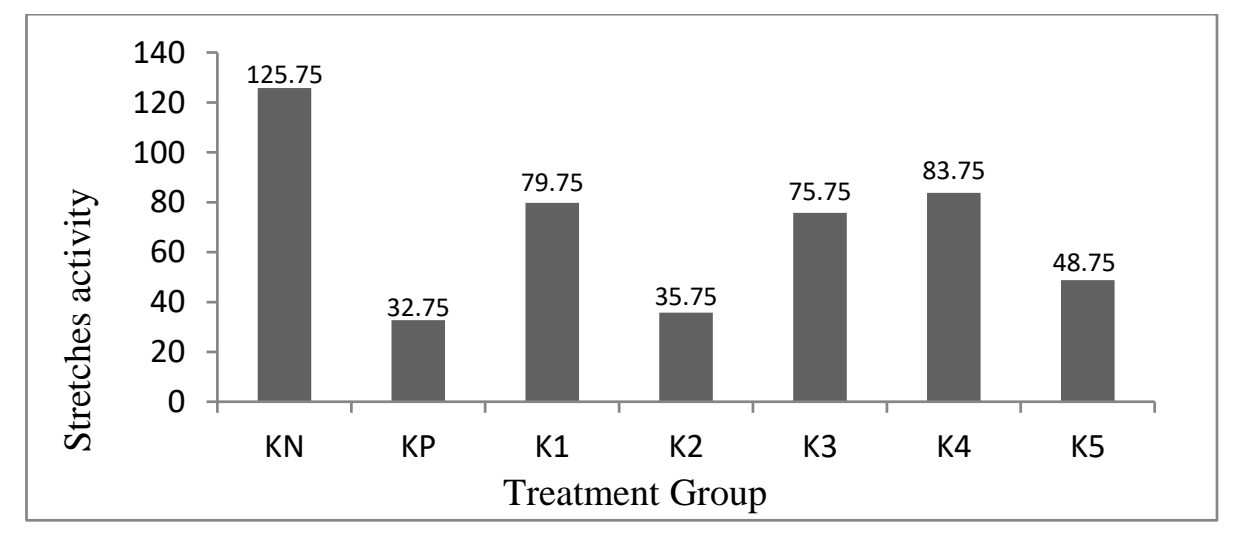

Figure 1 Mean number of stretches activity of mice after given treatments. KN= 0.5\%CMC, KP: Mefenamic acid; $\mathrm{K} 1=$ sukun extract of 200mg; K2= sukun:melinjo (50 :150)mg; K3= sukun:melinjo (100:100)mg; K4= sukun:melinjo (150 : 50)mg; K5=melinjo extract of $200 \mathrm{mg} / \mathrm{Kg} \mathrm{BW}$. 
One way ANOVA test results showed a $p$-value of 0.000 . This $p$-value indicates that the mean values of stretches activity among groups are significantly varied. The results of post hoc analysis using Duncan test can be described as follows. In comparison to the $0.5 \% \mathrm{CMC}$ suspension ( $\mathrm{KN}=$ negative control), all the dosage combinations of sukun and melinjo leaf extracts had a significant effect in reducing stretches activities in a dose-dependent manner.

Furthermore, when compared with standard drugs (KP=positive control)) the extracts labeled as $\mathrm{K} 2$ and $\mathrm{K} 5$ did not show a significant difference in the number of mice stretches activity. These data suggest that the combined extracts of sukun and melinjo with a dose ratio of $50: 150 \mathrm{mg} / \mathrm{kg}$ BW, and melinjo extract alone (200 mg/kg BW) have analgesic effects against acetic acid-induced pain in mice with similar efficacy with a conventional drug, mefenamic acid.

These data suggest that the combined extracts of sukun and melinjo with a dose ratio of $50: 150 \mathrm{mg} / \mathrm{kg}$ BW, and melinjo extract alone ( $200 \mathrm{mg} / \mathrm{kg} \mathrm{BW}$ ) have analgesic effects against acetic acid-induced pain in mice with similar efficacy with a conventional drug, mefenamic acid.

The percentage of protection against pain and the percentage of effectiveness of the combined extract of sukun and melinjo leaves can be seen in Figure 2. These data confirm the analgesic effect of the sukunt and melinjo leaf extracts as presented in Figure 1, that the extracts of sukun and melinjo with a dose combination of 50mg + 150mg (K2) and melinjo leaf extract alone at the dose of $200 \mathrm{mg} / \mathrm{kg} \mathrm{BW} \mathrm{(K5)} \mathrm{are} \mathrm{the} \mathrm{most} \mathrm{providing} \mathrm{protection} \mathrm{against} \mathrm{pain} \mathrm{and} \mathrm{are} \mathrm{most}$ effective.

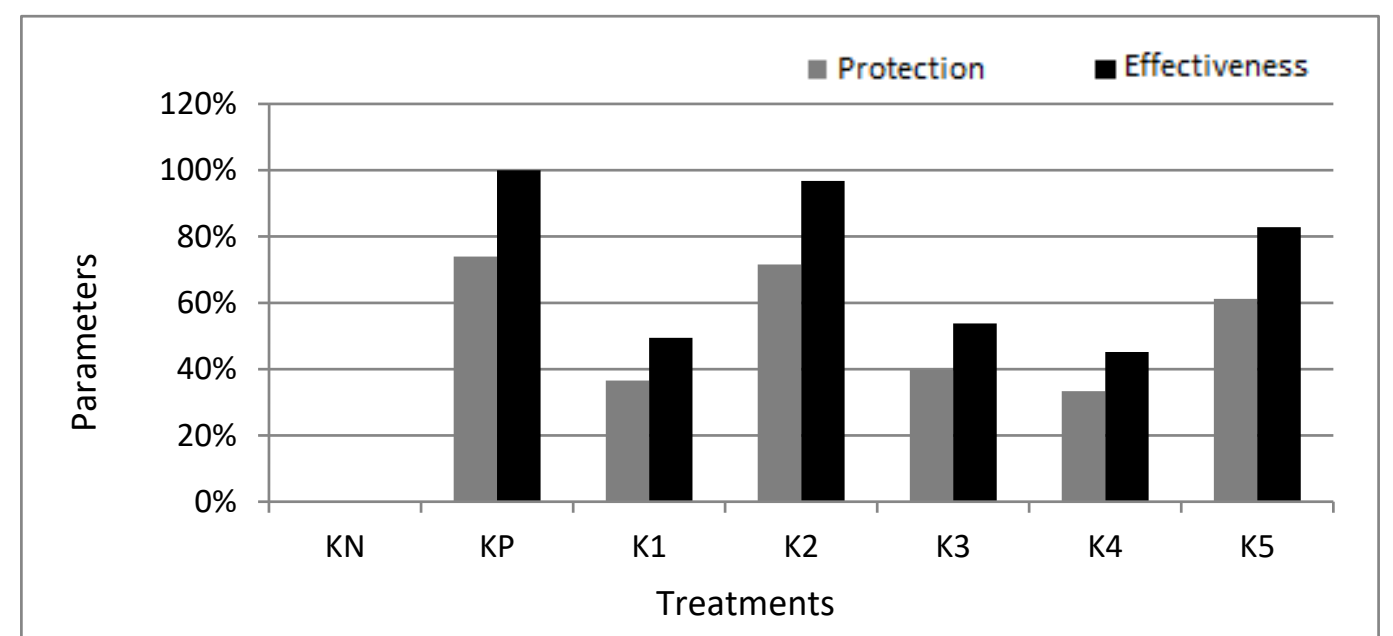

Figure 2 Percent protection and effectiveness of the extracts. KN= 0.5\%CMC, KP: Mefenamic acid; K1=sukun extract of 200mg; K2= sukun:melinjo (50 :150)mg; K3= sukun:melinjo (100:100)mg; K4= sukun:melinjo (150 : 50)mg; K5=melinjo extract of $200 \mathrm{mg} / \mathrm{Kg} \mathrm{BW}$.

The results of qualitative determination of the phytochemicals content in the ethanol extract of sukun and melinjo leaves are presented in Table 1. Except for steroid/terpenoid, all phytochemicals previously known to have analgesic effects namely flavonoids, alkaloids, and tannins are present in the leaf extracts of sukun and melinjo.

Table 1 Phytochemicals that are detected in ethanol extract of sukun and melinjo leaves

\begin{tabular}{|l|l|l|}
\hline Chemicals & Sukun leaves & Melinjo leaves \\
\hline Alkaloid & $(+)$ & $(+)$ \\
\hline Flavonoid & $(+)$ & $(+)$ \\
\hline Saponin & $(+)$ & $(+)$ \\
\hline Tanin & $(+)$ & $(+)$ \\
\hline Steroid/Terpenoid & $(-)$ & $(-)$ \\
\hline
\end{tabular}


The results of this study can be summarized as follows. The ethanol extracts of sukun and melinjo leaves were revealed to have anti-pain (analgesic) activity. The percentage of protection and effectiveness of the combined leaf extracts of the two plants equaled the standard drug, mefenamic acid. Phytochemical compounds that are known to have analgesic properties, such as alkaloids, flavonoids, saponins, and tannins were identified in the ethanol leaf extract of the two plants.

With regard to the breadfruit plant (Artocarpusaltilis), our findings appear to be somewhat different from previous reports. Pradhan et al., for example, failed to detect the presence of alkaloids and saponin in the petroleum ether, ethyl acetate, and methanol extract of sukun leaves. [14]. Similar results were also reported by Sikarwar et al. (2015) where the only confirmed phytochemicals were flavonoids, steroids, tannins [15]. Among the five bioactive compounds that are expected to have analgesic properties confirmed to be present in breadfruit leaf extracts by many phytochemical determination studies are flavonoids $[16,17]$.

Unlike the phytochemical content of breadfruit leaf extract, the phytochemicals that we found in the ethanol extract of melinjo leaves (Gnetumgnemon L.) were all confirmed by previous studies. Alkaloids, flavonoids, saponins, tannins and even the steroids were confirmed their presence in melinjo leaf extracts $[18,19]$.

The discrepancy in the results of phytochemical screening on sukun leaf extracts between previous studies and our findings may be due to differences in the solvents used in the extraction. Another possibility is that the content of alkaloids, saponins, tannins, and steroids in breadfruit leaves is too small. Whereas in the melinjo leaf extract the presence of these compounds is relatively high. This seems to be why the ingredients in $\mathrm{K} 2$ and K5 provide significant analgesic activity, closer to the standard drug. Both test ingredients, $\mathrm{K} 2$ and $\mathrm{K} 5$, contained a higher portion doses melinjo in comparison to the sukun. K2 contains melinjo extract with a combination dose of $150 \mathrm{mg}$ of melinjo extract and 50 mg of sukun extract per kg BW, while K5 contains only melinjo extract at a dose of $200 \mathrm{mg} / \mathrm{kg} \mathrm{BW}$.

There are many types of plants that are reported to contain alkaloids, tannins, saponins which are thought to be used as analgesic and anti-inflammatory drugs such as Anacardium occidentalis [20], Globimetular brounii [21], Papaver libanoticum [22].

The role of alkaloids, flavonoids, saponins, and tannins in providing analgesic and anti-inflammatory effects can be explained as follows. Alkaloids are thought to reduce pain by inhibiting the production of pro-inflammatory mediators such as IL-6, IL-1 $\beta$, iNOS, TNF- $\alpha$, COX-2, and MIP-2. The inhibition of production of these pro-inflammatory compounds, particularly NOx, was reported by Borgi et al. from their experiments using Zizyphus lotus plant extracts [23], and by Bribi et al. from their experiment utilizing extracts of the Fumaria capreolata plant [24]. Tannins, on the other hand, exert analgesic effects by inhibiting the release of pro-inflammatory compounds, cytokines [25].

\section{Conclusion}

Breadfruit leaf ethanol extract, either separately or in combination, had an analgesic effect on acetic acid-induced mice. However, the highest percentage of protection and effectiveness is the combination of breadfruit and melinjo extracts with a dose ratio of 50 and $150 \mathrm{mg} / \mathrm{kg} \mathrm{BW}$, or melinjo leaf extract alone with a dose of $200 \mathrm{mg} / \mathrm{kg}$ BW. Thus, the combination of sukun (Artocarpus altilis) and melinjo (Gnetum gnemon L.) leaf extracts deserves to be recommended as an analgesic drug.

\section{Compliance with ethical standards}

\section{Acknowledgments}

Authors sincerely thank to the Dean of The Faculty of Mathematics and Sciences, Tulangbawang University for his support in licensing the use of laboratory facilities and equipment in this research.

\section{Disclosure of conflict of interest}

Authors declare no conflict of interest. 


\section{References}

[1] Kumar K.H, Elavarasi P. Definition of pain and classification of pain disorders. Journal of Advanced Clinical \& Research Insights 2016; 3: 87-90. eJournals

[2] Ingrasciotta Y, Sultana J, GiorgianniF,Menditto E, Scuteri A, Tari M, et al. Analgesic drug use in elderly persons: Apopulation-based study in Southern Italy. PloSONE 2019; 14(9): e0222836. doi.org.Link

[3] Puspaningtyas A R.Drug Development of Mefenamic Acid Derivatives as Analgesic by Molecular Approach. International Journal of Pharmaceutical and Clinical Research 2017; 9(2): 123-130. IJPCR

[4] Safwan, Wirawan A, Dwi R.AktivitasAnalgetikEkstrakEtanolDaunMelinjo (Gnetumgnemon PadaMencitPutihJantan. Banjarmasin: JurnalIlmiahIbnuSina. 2016; 1(1);71-78

[5] Bakarbessy WHA, Wullur AC, and, Lolo WA.UjiEfekAnalgesikEkstrakEtanolDaunSukun (Artocarpusaltilis) PadaTikusPutihGalurWistar (Rattusnorvegicus).PHARMACON JurnalIlmiahFarmasi - Unsrat, 2016; 5(2):220227. Pharmacon

[6] Deni F, Adelisa M, Delia D.AktivitasAnalgetikaEkstrakEtanolDaunSukun (Artocarpusaltilis) TerhadapMencitPutihJantanPutih Yang di InduksiAsamAsetat. Cirebon: Medical Sains. 2019; 4(1):13-18.

[7] Aronson JK. Meyler's Side Effects of Analgesics and Antiinflammatory Drugs. Elsevier, Amsterdam, Netherland. Wordpress 2010

[8] López-Posadas, R., Ballester, I., Mascaraque, C., Suárez, M. D., Zarzuelo, A., Martínez-Augustin, O., \& Sánchez de Medina, F. Flavonoids exert distinct modulatory actions on cyclooxygenase 2 and NF-kappaB in an intestinal epithelial cell line (IEC18). British journal of pharmacology, 2010; 160(7), 1714-1726. doi.org.Link

[9] Navarro JF, Burón E and Martín-Lópe M. Anxiolytic-like activity of SB-205384 in the elevated plus maze test in mice. Psicothema 2006; 18(1): 100-104. Psicothema

[10] Triswanto S, Susiyanto P. UjiEfekAnalgetikEkstrakEtanolDaunKersen (Muntingiacalabura L.) PadaMencitPutihJantan (Musmusculus) DenganInduksiNyeriAsamAsetat. J IlmManuntung 2016; 2(2):147-53 [7].

[11] Singh A, Singh A, Chouhan O, Tandi GP, Dua M, Gehlot A. Anti-inflammatory and analgesic activity of aqueous extracts of dried leaves of Murrayakoenigii Linn.Natl J Physiol Pharm Pharmacol 2016; 6:286-290. Link-njppp

[12] Galani VJ, Patel BG. Analgesic and Anti-inflammatory Activity of Argyreiaspeciosa and Sphearanthusindicus in the Experimental Animals. Glob J Pharmacol 2010; 4(3):136-41.

[13] Mera IFG, Falconí DEG and Córdova VM. Secondary metabolites in plants: main classes, phytochemical analysis and pharmacological activities. Date citation: 2019; Oct 13, 2020. Available from: http://www.revistabionatura.com

[14] Pradhan C., Mohanty M. \& Rout A. O Phytochemical screening and comparative bioefficacy assessment of Artocarpusaltilis leaf extracts for antimicrobial activity, Frontiers in Life Science, 2012: 6:3-4, 71-76, D0I: $10.1080 / 21553769.2013 .765811$

[15] Sikarwar MS, Hui BJ, Subramaniam K, Valeisamy BD, Yean LK and Balaji K. Pharmacognostical, Phytochemical and Total Phenolic Content of Artocarpusaltilis (Parkinson) Fosberg Leaves. J App Pharm Sci, 2015; 5 (05): 094100. japsonline

[16] H Rante, G Alamand M Irwan. a -Glucosidase inhibitory activity of breadfruit leaf extract (Artocarpusaltilis (parkinson) fosberg) J. Phys.: Conf. Ser. 1341 072015. iopscience2019

[17] Sivagnanasundaram P. and Karunanayake KOLC. Phytochemical Screening and Antimicrobial Activity of Artocarpusheterophyllus and Artocarpusaltilis Leaf and Stem Bark Extracts. OUSL Journal 2015; Vol. 9, (pp. 117). ouslj.sljol.info/articles

[18] Bharali P, Dutta P, Kalita MC, Das AK and Tag H. Evaluation of antioxidant and proximate compositions of the leaf extract of Gnetumgnemon L. Int. Res. J. Pharm. 2018; 9 (10). irjponline

[19] Barua CC, Haloi P and Barua IC. Gnetumgnemon Linn. : A Comprehensive Review on its Biological, Pharmacological and Pharmacognostical Potentials. International Journal of Pharmacognosy and Phytochemical Research 2015; 7(3); 531-539. Researchgate 
[20] Onasanwo SA, Fabiyi TD, Oluwole FS and Olaleye SB. Analgesic and anti-inflammatory properties of the leaf extracts of Anacardiumoccidentalis in the laboratory rodents. Niger. J. Physiol. Sci. 27 June $2012 ; 065$ - 071. http://www.bioline.org.br/pdf?np12024

[21] Atiku I, Sule MI, Pateh UU, Musa AM, Ya'u J, et al. Phytochemical, Anti-inflammatory and Analgesic Studies of the Crude Ethanolic Leaf Extract of Globimetularbrounii Van Tieghem (Family: Loranthaceae). Nat Prod Chem Res 3:193. doi:10.4172/2329-6836.1000193 2015

[22] Hijazi MA, El-Mallah A, Aboul-Ela M, and Ellakany A. Evaluation of Analgesic Activity of Papaverlibanoticum Extract in Mice: Involvement of Opioids Receptors. Hindawi Evidence-Based Complementary and Alternative Medicine Volume 2017, Article ID 8935085, 13 pages. https://doi.org/10.1155/2017/8935085

[23] Bribi N, Algieri F, Rodriguez-Nogales A, Garrido-Mesa J, Vezza T, Maiza F, Utrilla MP, Rodriguez-Cabezas MA and Galvez J, "Antinociceptive and Anti-Inflammatory Effects of Total Alkaloid Extract from Fumariacapreolata", Hindawi Evidence-Based Complementary and Alternative Medicine, vol. 2015,Article ID 736895, 7 pages, 2015. https://doi.org/10.1155/2015/736895

[24] W. Borgi, M.C. Recio, J.L. Ríos, and N. Chouchane. Anti-inflammatory and analgesic activities of flavonoid and saponin fractions from Zizyphus lotus (L.) Lam. South African Journal of Botany 74 2008; 320- 324. Core.ac.uk

[25] ElwiraSieniawska.Activities of Tannins - From In Vitro Studies to Clinical Trials. Natural Product Communications,2015; 10 (11): 1877 - 1884. Sagepub 